\title{
Clone-Specific Response in Leaf Nitrate Reductase Activity among Unrelated Hybrid Poplars in relation to Soil Nitrate Availability
}

\author{
Julien Fortier, ${ }^{1,2}$ Benoit Truax, ${ }^{1}$ France Lambert, ${ }^{1}$ \\ Daniel Gagnon, ${ }^{1,2,3}$ and Normand Chevrier ${ }^{4}$ \\ ${ }^{1}$ Fiducie de Recherche sur la Forêt des Cantons-de-l'Est, Eastern Townships Forest Research Trust, 1 Rue Principale, \\ St-Benoît-du-Lac, QC, Canada JOB 2MO \\ ${ }^{2}$ Centre d'Étude de la Forêt (CEF), Université du Québec à Montréal, C.P. 8888, Succursale Centre-Ville, \\ Montréal, QC, Canada H3C 3P8 \\ ${ }^{3}$ Department of Biology, University of Regina, 3737 Wascana Parkway, Regina, SK, Canada S4S 0A2 \\ ${ }^{4}$ Département des Sciences Biologiques, Université du Québec à Montréal, C.P. 8888, Succursale Centre-Ville, \\ Montréal, QC, Canada H3C 3P8
}

Correspondence should be addressed to Julien Fortier, fortier.julien@courrier.uqam.ca

Received 17 September 2012; Accepted 26 October 2012

Academic Editor: Guy R. Larocque

Copyright (c) 2012 Julien Fortier et al. This is an open access article distributed under the Creative Commons Attribution License, which permits unrestricted use, distribution, and reproduction in any medium, provided the original work is properly cited.

\begin{abstract}
In this field study, we used in vivo NRA activity in hybrid poplar leaves as an indicator of $\mathrm{NO}_{3}{ }^{-}$assimilation for five unrelated hybrid poplar clones. We also examined if leaf NRA of these clones is influenced to the same extent by different levels of soil $\mathrm{NO}_{3}{ }^{-}$ availability in two riparian agroforestry systems located in pastures. Leaf NRA differences of more than one order of magnitude were observed between the clones, clearly showing their different abilities to reduce $\mathrm{NO}_{3}{ }^{-}$in leaves. Clone DxN-3570, a P. deltoides $\mathrm{x}$ P. nigra hybrid (Aigeiros intrasectional hybrid), always had the highest leaf NRA during the field assays. This clone was also the only one to increase its leaf NRA with increasing $\mathrm{NO}_{3}{ }^{-}$soil availability, which resulted in a significant Site $\mathrm{x}$ Clone interaction and a positive relationship between soil $\mathrm{NO}_{3}{ }^{-}$concentration and NRA. All of the four other clones studied had one or both parental species from the Tacamahaca section. They had relatively low leaf NRA and they did not increase their leaf NRA when grown on the $\mathrm{NO}_{3}{ }^{-}$rich site. These results provide evidence that $\mathrm{NO}_{3}{ }^{-}$assimilation in leaves varies widely among hybrid poplars of different parentages, suggesting potential preferences for $\mathrm{N}$ forms.
\end{abstract}

\section{Introduction}

Poplars (Populus spp.) are commonly planted for production and restoration purposes in different plantation systems, environments (agricultural land, abandoned farmland, clearcut forest, contaminated sites, riparian buffers, intercropping systems, etc.), and climates [1-7]. A large number of poplar hybrids exist throughout the world and they exhibit wide variations in functional traits (i.e., morphological, physiological, and phenological characteristics) $[8,9]$.

Because they can be clonally propagated with ease, poplars from the Tacamahaca and the Aigeiros sections and their hybrids form the basis of most poplar breeding programs worldwide [10]. Although they are all pioneer species that mainly occur in coastal, riparian, alluvial, and bottomland environments, poplars from these two sections differ widely in their natural distributions, as they are adapted to different soil and climatic conditions [11]. Poplars from the Tacamahaca section are mostly associated with riparian or wetland habitats [11]. They are widely distributed in the northern latitudes, with some species growing to the latitudinal or altitudinal limits of trees [11]. Poplars from the Aigeiros section are better adapted to riparian soils in the bottomlands of temperate and arid regions [11, 12].

Poplars from the Tacamahaca and the Aigeiros sections also show marked differences in their $\mathrm{N}$-form preferences 
$[13,14]$. This is because organic matter mineralization processes are strongly influenced by habitat characteristics such as climate (temperature and precipitation), soil $\mathrm{pH}$, and water table depth [15-17]. For example, balsam poplar (Populus balsamifera), growing as far north as $69^{\circ}$ latitude in Alaska [11], is able to assimilate directly both $\mathrm{NH}_{4}{ }^{+}$ and amino acids, with no apparent preference [18], and its physiological capacity to assimilate $\mathrm{NH}_{4}{ }^{+}$is greater than for $\mathrm{NO}_{3}{ }^{-}$[13]. Fertilisation trials also show that P. balsamifera and poplar hybrids with one parental species related to the Tacamahaca section, tended to grow best with $\mathrm{NH}_{4}{ }^{+}$ fertilisation over $\mathrm{NO}_{3}{ }^{-}$fertilisation [19]. Conversely, a high $\mathrm{NO}_{3}{ }^{-}: \mathrm{NH}_{4}{ }^{+}$ratio in the soil solution strongly stimulates root development in Eastern cottonwood (P. deltoides) [20].

Nitrogen form preferences have been shown to be closely linked to the ability of tree species to reduce $\mathrm{NO}_{3}{ }^{-}$from the soil solution [21-23]. Because nitrate reductase (NR) is a substrate-induced enzyme [24], in vivo nitrate reductase activity (NRA) in the leaves and in roots has proven to be a useful indicator of $\mathrm{NO}_{3}{ }^{-}$assimilation in a wide range of species, management practices, and environmental conditions $[23,25-31]$.

In poplars, Dykstra [32] detected important differences in leaf NRA between hybrid poplar clones $P$. tristis $\mathrm{x}$ balsamifera and $P$. deltoides $\mathrm{x}$ nigra. In free-growing populations, similar observations were reported by $\mathrm{Al}$ Gharbi andHipkin [25] when $P$. alba, $P$. deltoides x nigra, and $P$. tremula were compared. More recently, Black et al. [33] reported that NRA in $P$. tremula $\mathrm{x}$ alba was at least 10 -fold greater in leaves than in stems or in roots at all nitrate availabilities. These authors concluded that most nitrate assimilation occurs in poplar leaves, a finding that was later corroborated by Rosenstiel et al. [34] in Eastern cottonwood (P. deltoides). Balsam poplar also showed slightly higher NRA in leaves than in roots when substrate was not limiting [29].

Relationships between soil N availability and NRA in poplars have also been documented. Min et al. [21] showed that NRA in roots and in leaves of trembling aspen $(P$. tremuloides) is rapidly induced following $\mathrm{NO}_{3}{ }^{-}$exposure, with leaves having the greatest activity. Higher NRA was also observed in the $\mathrm{N}$ fertilisation treatment for $P$. deltoides $\mathrm{x}$ $P$. nigra hybrid [35]. Nitrate reductase activity in leaves and roots was also greater when $P$. tremula $\mathrm{x}$ alba was grown in the highest external $\mathrm{NO}_{3}{ }^{-}$concentration [33].

In this field study, we use in vivo NRA activity in hybrid poplar leaves as an indicator of $\mathrm{NO}_{3}{ }^{-}$assimilation [29] in five unrelated hybrid poplar clones: (1) Populus trichocarpa $\mathrm{x} P$. deltoides (TxD-3230), (2) P. deltoides $\mathrm{x} P$. nigra (DxN-3570), (3) P. x canadensis $\mathrm{x} P$. maximowiczii (DNxM-915508), (4) P. nigra x P. maximowiczii (NxM3729), and (5) P. maximowiczii x P. balsamifera (MxB915311). We hypothesize that the intrasectional hybrid from the Aigeiros section (DxN hybrid) should exhibit a higher NRA than the intersectional hybrids (TxD, NxM, and DNxM hybrids) and the intrasectional hybrid from the Tacamahaca section (MxB hybrid). This hypothesis should be supported because parental species of the DxN hybrid are adapted to temperate floodplain environments, where $\mathrm{NO}_{3}{ }^{-}$is the dominant $\mathrm{N}$-form [36], while parental species of the $\mathrm{MxB}$ hybrid are adapted to riparian habitats and wetland ecotones of colder climates (Alaska, northern Canada, Siberia) [11], where $\mathrm{NH}_{4}{ }^{+}$is the dominant $\mathrm{N}$-form in soils [37], although hydrologically driven $\mathrm{NO}_{3}{ }^{-}$input occurs periodically [29]. In this study, we also examine if leaf NRA of these unrelated hybrid poplar clones is influenced to the same extent by different levels of soil $\mathrm{NO}_{3}{ }^{-}$availability within two riparian agroforestry systems located in pastures.

\section{Materials and Methods}

2.1. Study Sites. In May 2003, two multiclonal hybrid poplar riparian buffers were planted along headwater streams in the Eastern Townships region of southern Quebec, Canada. The buffer had cumulated five years of growth in 2007, the year of the study. The two riparian buffer study sites (Bromptonville: $45^{\circ} 29 \mathrm{~N} ; 71^{\circ} 59 \mathrm{~W}$; Magog: $45^{\circ} 14 \mathrm{~N}$; $72^{\circ} 07 \mathrm{~W}$ ) are located in pastures of the regional landscape unit of Sherbrooke [38]. This landscape unit is characterised by gentle slopes, a continental subhumid moderate climate, a growing season of 180-190 days, and a precipitation regime of 1000-1100 mm/year [39]. Cattle densities at the two pasture sites are $0.6 \mathrm{cowha}^{-1}$ at Bromptonville and 0.2 cow ha ${ }^{-1}$ at Magog. The Bromptonville site is fertilized each year with cow manure, while the Magog site receives no fertilisation. The soil of the Bromptonville site developed on glacial outwash, deposited over lacustrine clay [40]. It is well-drained and named "Sheldon sandy loam" [40]. The soil of the Magog site developed on glacial till. It is imperfectly drained and named "Magog stony loam" [40]. Much higher aboveground biomass (including leaves) have also been measured at the fertile site of Bromptonville, one year following this study (6th growing season) [1]. Site and soil characteristics are presented in Table 1. Additional site and soil characteristics are available in other related studies $[1,7,41]$.

Five unrelated hybrid poplar clones were used in this study: (1) Populus trichocarpa x P. deltoides (TxD-3230), (2) P. deltoides $\mathrm{x} P$. nigra (DxN-3570), (3) P. x canadensis $\mathrm{x} P$. maximowiczii (DNxM-915508), (4) P. nigra $\mathrm{x} P$. maximowiczii (NxM-3729), and (5) P. maximowiczii x $P$. balsamifera (MxB-915311) (Table 2). The five poplar clones were chosen because they have different growth patterns, physiological characteristics, and because they had been selected for superior disease resistance/tolerance and growth characteristics in trials in southern Quebec [42].

2.2. Experimental Design. A randomized block design was used at each of the two sites, with 4 blocks (replicates) and 5 hybrid poplar clones (treatments) for a total of 40 experimental plots. Each block contains 5 experimental plots (one clone per plot). Plots are $4.5 \mathrm{~m}$ wide and $9 \mathrm{~m}$ long $\left(40.5 \mathrm{~m}^{2}\right)$. Each plot contains 9 trees from a single clone (3 rows, 3 trees/row). Each tree is spaced $3 \mathrm{~m}$ on the row and the rows are $1.5 \mathrm{~m}$ apart. Tree rows were planted parallel to stream bank. A total of 180 hybrid poplars where planted at each site (36 trees of each clone) for a total of 360 hybrid poplars, two blocks on each side of the stream. This design 
TABle 1: Site and soil characteristics at the two riparian sites: elevation, mean aboveground poplar dry biomass (including leaves), soil drainage class, $\mathrm{pH}$, and nutrient supply rate $\left(\mu \mathrm{g} 10 \mathrm{~cm}^{-2} 15 \mathrm{~d}^{-1}\right)$. The $\mathrm{NO}_{3}{ }^{-}: \mathrm{NH}_{4}{ }^{+}$nutrient supply rate molar ratio is also indicated. For nutrient supply rate, PRS-Probes were buried during a 15 day period in late August 2007.

\begin{tabular}{|c|c|c|c|c|c|c|c|c|c|c|c|c|}
\hline Sites & $\begin{array}{l}\text { Elev. } \\
(\mathrm{m})\end{array}$ & $\begin{array}{l}\text { Poplar biomass } \\
\quad\left(\mathrm{kg} \mathrm{tree}^{-1}\right)^{1}\end{array}$ & Drainage $^{2}$ & $\mathrm{pH}^{1}$ & $\mathrm{NO}_{3}{ }^{-}$ & $\mathrm{NH}_{4}^{+}$ & $\mathrm{NO}_{3}{ }^{-}: \mathrm{NH}_{4}^{+}$ & $\mathrm{P}$ & $\mathrm{Ca}$ & K & $\mathrm{Mg}$ & $\mathrm{Mn}$ \\
\hline Bromptonville & 140 & 58.9 & Good & 6.36 & 69.2 & 11.4 & 1.8 & 8.37 & 1291 & 506 & 254 & 2.8 \\
\hline Magog & 208 & 12.2 & Imperfect & 5.81 & 24.7 & 16.7 & 0.4 & 4.24 & 710 & 102 & 492 & 17.8 \\
\hline SE & - & - & - & 0.03 & 9.7 & 1.0 & - & 1.16 & 57 & 19 & 23 & - \\
\hline$P<$ & - & 一 & - & 0.001 & 0.01 & 0.01 & - & 0.05 & 0.001 & 0.001 & 0.001 & NS \\
\hline
\end{tabular}

${ }^{1}$ Poplar aboveground biomass per tree data and $\mathrm{pH}$ data were taken from Fortier et al. [1].

${ }^{2}$ Soil drainage classes were obtained from Cann and Lajoie [40].

allowed us to test 5 poplar clones in two different riparian environments simultaneously, a common procedure in crop cultivar trials [43].

2.3. Soil Nutrient Availability. Nutrient availability in the hybrid poplar buffers was determined using Plant Root Simulator (PRS-Probes) technology from Western Ag Innovations Inc., Saskatoon, Canada. The PRS-probes consist of an ion exchange membrane encapsulated in a thin plastic probe, which is inserted into the ground with little disturbance of soil structure. Nutrient availability predicted with this method is generally significantly correlated with conventional soil extraction methods over a wide range of soil types [44].

Three pairs of probes (an anion and a cation probe in each pair) were buried along the middle row (of 3 rows parallel to stream bank) of poplars in each experimental plot (40 plots). At each site, burial length was 15 days, starting in mid-August 2007. After removal, probes were washed in the field with deionised water and returned to Western Ag Labs for analysis $\left(\mathrm{NO}_{3}{ }^{-}, \mathrm{NH}_{4}{ }^{+}, \mathrm{P}, \mathrm{K}, \mathrm{Ca}, \mathrm{Mg}\right.$, and $\left.\mathrm{Mn}\right)$. Composites were made by combining the three pairs of probes in each experimental plot. Probe supply rates are reported as $\mu \mathrm{mol}$ of nutrient $10 \mathrm{~cm}^{-2} 15$ days $^{-1}$ and are presented in Table 1.

2.4. Nitrogen Mineralization Rate. A sequential coring technique was used to measure nitrification and ammonification rates at the two riparian sites [45]. In each experimental plot, two pairs of hard PVC tubes $(20 \mathrm{~cm}$ in length and $5.5 \mathrm{~cm}$ in diameter) were inserted $15 \mathrm{~cm}$ vertically into the soil. The first pair of tubes and their soil content were immediately removed and placed in a portable ice box and transported to the lab for extraction with $2 \mathrm{M} \mathrm{KCl} \mathrm{[46]} \mathrm{within} 24 \mathrm{~h}$. The content of each pair of tubes was mixed thoroughly and duplicate extractions were made for each composite. During the following days, the concentration of $\mathrm{NO}_{3}{ }^{-}$and $\mathrm{NH}_{4}{ }^{+}$ were determined using a Tecator FIAstar continuous flow analyzer.

The second pair of tubes remained in the soil for a 24 day period (from 17 July to 9 August 2007). They were capped with tape to prevent $\mathrm{N}$ loss from leaching by rain. A small hole was pierced laterally on each tube ( $1 \mathrm{~cm}$ from the top) to allow aeration. After 24 days, tubes were removed from the soil and the same procedure (as for initial tubes) was used in order to determine concentrations of $\mathrm{N}$-forms. Nitrification was calculated as the $\mathrm{NO}_{3}{ }^{-}$concentration of the soil at the end of the incubation period minus the $\mathrm{NO}_{3}{ }^{-}$concentration at the beginning. Ammonification was calculated the same way.

\subsection{Nitrate Reductase Activity Assay}

2.5.1. Enzymatic Kinetics. In order to verify that the substrate $\left(\mathrm{KNO}_{3}\right)$ concentration that would be used in further NRA experiments was not limiting, we evaluated the effect of different substrate concentrations $(0,1,5,10,15,20,40$, 100,150 , and $200 \mathrm{mM}$ ) on NRA of two representative hybrid poplar clones (DxN-3570 and MxB-915311).

Measurement of the in vivo NRA in poplar leaves was done according to the method developed by Jaworski [47] and optimized for broadleaf tree species [30]. In early summer (June 29, 2007), leaves from the upper shoots were taken at noon at the Bromptonville site. For each of the two clones, a composite sample was made by combining two leaves from two different trees. The plastochron index was used to select fully expanded leaves at the same developmental stage [48]. Leaf plastochron index 7 (LPI 7) was selected for all samples. Samples were put in a plastic bag and immediately placed in a portable icebox $\left(4^{\circ} \mathrm{C}\right)$. The sampling operations were always done within $1 \mathrm{~h}$ and plant material was brought back to the lab within $30 \mathrm{~min}$ after sampling.

At the lab, the leaves from each sample were cut into small pieces $(2 \times 2 \mathrm{~mm})$ and $0.1 \mathrm{~g}$ of fresh tissue, in duplicate for each composite sample, was placed in a test tube containing $5 \mathrm{~mL}$ of incubating solution ( $\mathrm{pH} \mathrm{7.5),} \mathrm{containing} 100 \mathrm{mM}$ phosphate buffer, 1.5\% 1-propanol, and the different $\mathrm{KNO}_{3}$ concentrations. Tissues samples and solutions were vortexed for $2 \mathrm{~min}$ to enhance infiltration of the assay medium. Each test tube was sealed and incubated in the dark for $1 \mathrm{~h}$ at $30^{\circ} \mathrm{C}$. A blank was done for each composite sample. The enzymatic reaction was stopped by immersing the tubes in boiling water over five minutes. The colorimetric determination of the reaction was achieved by mixing $1 \mathrm{~mL}$ of incubation solution with $1 \mathrm{~mL}$ of $0.02 \% \mathrm{NED}$ and $1 \mathrm{~mL}$ of sulphanilamide. After $30 \mathrm{~min}$, the samples were centrifuged at $2000 \times \mathrm{g}$ for $5 \mathrm{~min}$ and the supernatant was read in a spectrophotometer at $540 \mathrm{~nm}$. Nitrate reductase activity is expressed as the amount 
TABLE 2: Name, parentage, section, and origin of the five hybrid poplar clones.

\begin{tabular}{|c|c|c|c|c|}
\hline Clone number & Scientific name (common name) & Parentage & Section & Origin \\
\hline 3230 & P. x generosa A. Henry (Boelare) & $\mathrm{TxD}$ & Tacamahaca $\mathrm{x}$ Aigeiros & Belgium \\
\hline 3570 & P. $\mathrm{x}$ canadensis Moench & DxN & Aigeiros $\mathrm{x}$ Aigeiros & Belgium \\
\hline 3729 & P. nigra $\mathrm{x}$ P. maximowiczii (NM6) & $\mathrm{NxM}$ & Aigeiros x Tacamahaca & Germany \\
\hline 915311 & P. maximowiczii $\mathrm{x}$ P. balsamifera & $\mathrm{MxB}$ & Tacamahaca x Tacamahaca & Québec \\
\hline 915508 & P. $\mathrm{x}$ canadensis $\mathrm{x} P$. maximowiczii & DNxM & (Aigeiros $\mathrm{x}$ Aigeiros) $\mathrm{x}$ Tacamahaca & Québec \\
\hline
\end{tabular}

of $\mathrm{NO}_{2}{ }^{-}$measured in the test tube after the $1 \mathrm{~h}$ incubation period, calculated for $1 \mathrm{~g}$ of dry leaf tissue.

2.5.2. Effect of Leaf Age on Hybrid Poplar NRA. The effect of leaf age on NRA was assessed for the five hybrid poplar clones. The same procedure as the one described above was employed, except that leaf samples from LPI 3 to LPI 9 were collected from the five clones at the Bromptonville site (July $2-3,2007)$. Based on the enzymatic kinetics assay, we used a substrate $\left(\mathrm{KNO}_{3}\right)$ concentration of $40 \mathrm{mM}$.

2.5.3. Determination of Hybrid Poplar NRA at the Two Riparian Buffer Sites. In mid July (July 10 and 11, 2007) and late August (August 28 and 29, 2007), NRA assays were performed with plant material from the two riparian buffer sites (Bromptonville and Magog). In each experimental plot ( $n$ of plots $=40$ ), a composite sample was made by combining two leaves from two different trees of a single clone (one clone per plot). Leaf samples were collected in the same manner as in the previous assays and the same procedure was used for NRA determination. Based on the observations concerning the effect of leaf age on NRA, plant material corresponding to LPI 6 was used for all clones in this assay.

2.6. Statistical Analysis. ANOVA tables were constructed in accordance with Peterson [49], and degrees of freedom, sum of squares, mean squares, and $F$ values were computed. When a factor was declared statistically significant (Sites, Clones and Sites $\mathrm{x}$ Clones interaction), the standard error of the mean (SE) was used to evaluate differences between means for four levels of significance $(P<0.1, P<0.05$, $P<0.01$, and $P<0.001)$. All of the ANOVAs were run with the complete set of data ( 2 sites, 5 clones, and 4 blocks $=40$ experimental plots). Results of enzymatic kinetics and effect of leaf age on NRA are presented as means with standard deviations (SD).

\section{Results}

3.1. Nitrogen Supply Rate, Soil $N$ Concentration, and $N$ Mineralization. Nitrate supply rate was approximately three times higher at the Bromptonville site compared to the Magog site, while $\mathrm{NH}_{4}{ }^{+}$supply rate was approximately 50\% higher at the Magog site (Table 1). This resulted in very contrasting molar ratios of $\mathrm{NO}_{3}{ }^{-}: \mathrm{NH}_{4}{ }^{+}$availability (1.8 at Bromptonville versus 0.4 at Magog) (Table 1).

Initial $\mathrm{NO}_{3}{ }^{-}$concentration measured at the beginning of the mineralization study was approximately $60 \%$ higher at the Bromptonville site, while initial $\mathrm{NH}_{4}{ }^{+}$concentration was more than twice higher at the Magog site (Table 3). After the incubation period (24 days), a three-fold increase in $\mathrm{NO}_{3}{ }^{-}$concentration occurred at Bromptonville, while only a two-fold increase was observed at Magog. This resulted in a higher nitrification rate at Bromptonville. At both sites, $\mathrm{NH}_{4}{ }^{+}$concentration in soil showed a decrease after the incubation period because of high nitrification rates. Because nitrification rate was higher at Bromtptonville, the decrease in $\mathrm{NH}_{4}{ }^{+}$concentration was also higher, although ammonification rates were not statistically different between the two sites.

Strong positive linear relationships were obtained between $\mathrm{NO}_{3}{ }^{-}$supply rate measured during a 15 day period with ion exchange membrane (PRS-probes) and initial $\mathrm{NO}_{3}{ }^{-}$concentration in soil tube soils prior to incubation (Figure 1(a)), final $\mathrm{NO}_{3}{ }^{-}$concentration in soil tube soils following a 24 day incubation period (Figure 1(b)) and nitrification rate in soil tube soils during a 24 day incubation period (Figure 1(c)).

3.2. Nitrate Reductase Activity. The enzymatic kinetics assay revealed that leaf NRA was much higher for clone DxN-3570 than for clone MxB-915311 at any substrate concentration (Figure 2). Results also show that both of these clones had their highest leaf NRA at a substrate concentration of $20 \mathrm{mM}$ $\mathrm{NO}_{3}{ }^{-}$. In fact, for both of these clones a similar pattern of NR induction was observed. For substrate concentrations lower than $20 \mathrm{mM} \mathrm{NO}_{3}{ }^{-}$, leaf NRA increased very rapidly in relation to substrate availability and afterwards decreased slightly at higher $\mathrm{NO}_{3}{ }^{-}$concentrations (Figure 2).

The effect of leaf age (developmental stage) on NRA was different from one clone to another (Figure 3). At all developmental stages, leaf NRA of clone DxN-3570 was higher than any other clones and showed a rapid decrease from LPI3 to LPI9. In younger leaves, clone NxM-3729 had a higher leaf NRA value than clones TxD-3230, MxB915311, and DNxM-915508, at most developmental stages. For the three other clones (TxD-3230, MxB-915311, and DNxM-915508), leaf NRA was equal or below $1 \mu \mathrm{mol}$ $\mathrm{NO}_{2}{ }^{-} \mathrm{g}_{\mathrm{dw}}{ }^{-1} \mathrm{~h}^{-1}$, with a maximum value observed at LPI 3 (Figure 3). At almost all leaf developmental stages, clone DNxM-915508 had the lowest NRA.

For the two NRA assays at the two riparian sites (July 10-11 and August 28-29 2009), a significant Site x Clone interaction was detected by the ANOVA (Figure 4). During the July assay, NRA of clone DxN-3570 was statistically higher than any other clones at both sites. However, during 
TABLE 3: Nitrification and ammonification rates measured during a 24 days period at the two riparian sites (July 17-August 9, 2007). Nitrate and ammonium concentrations at the beginning (initial) and at the end (final) of the in situ incubation period are also presented.

\begin{tabular}{lcccccc}
\hline Sites & $\begin{array}{c}\mathrm{NO}_{3}{ }^{-} \text {initial } \\
\left(\mathrm{mg} \mathrm{kg}^{-1}\right)\end{array}$ & $\begin{array}{c}\mathrm{NO}_{3}{ }^{-} \mathrm{final} \\
\left(\mathrm{mg} \mathrm{kg}^{-1}\right)\end{array}$ & $\begin{array}{c}\text { Nitrification rate } \\
\left(\mathrm{mg} \mathrm{kg}^{-1} 24 \mathrm{~d}^{-1}\right)\end{array}$ & $\begin{array}{c}\mathrm{NH}_{4}{ }^{+} \text {initial } \\
\left(\mathrm{mg} \mathrm{kg}^{-1}\right)\end{array}$ & $\begin{array}{c}\mathrm{NH}_{4}{ }^{+} \text {final } \\
\left(\mathrm{mg} \mathrm{kg}^{-1}\right)\end{array}$ & $\begin{array}{c}\text { Ammonification rate } \\
\left(\mathrm{mg} \mathrm{kg}^{-1} 24 \mathrm{~d}^{-1}\right)\end{array}$ \\
\hline Bromptonville & 5.07 & 16.95 & 11.87 & 1.23 & 0.29 & -0.93 \\
Magog & 3.13 & 6.29 & 3.15 & 2.92 & 2.71 & -0.21 \\
SE & 0.38 & 1.76 & 1.55 & 0.26 & 0.30 & - \\
$P<$ & 0.01 & 0.001 & 0.001 & 0.001 & 0.001 & $\mathrm{NS}$ \\
\hline
\end{tabular}

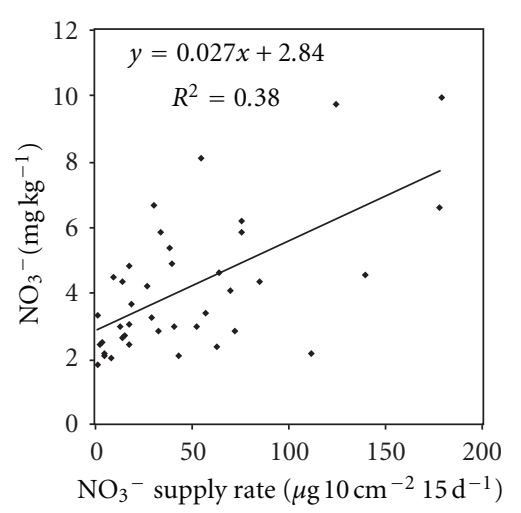

(a)

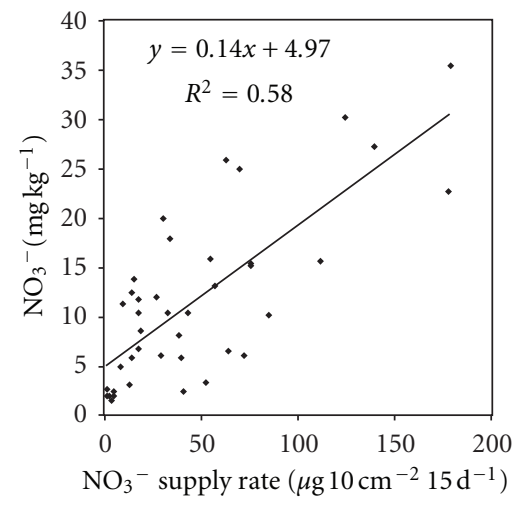

(b)

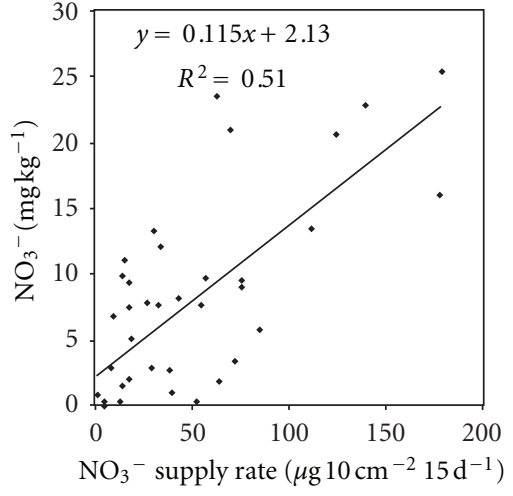

(c)

FIGURE 1: Linear relationships between soil $\mathrm{NO}_{3}{ }^{-}$supply rate and soil tube in situ incubations in riparian soils for 3 variables: (a) initial $\mathrm{NO}_{3}{ }^{-}$concentration in soil tube soils prior to incubation, (b) final $\mathrm{NO}_{3}{ }^{-}$concentration in soil tube soils following a 24 day incubation period, and (c) nitrification rate in soil tube soils during a 24 day incubation period. All relationships are significant at $P<0.001$.

the August assay, only NRA of clone DxN-3570 at the Bromptonville site was statistically higher than any other clones at both sites. During both assays, clone DxN-3570 had a significantly higher NRA at the Bromptonville site than at the Magog site, while NRA of the four other clones was generally higher at the Magog site or equivalent to what was observed at the Bromptonville site. The NRA of clone DxN-3570 at Bromptonville was almost twice as high in the August assay as in the July assay, while little difference in NRA was observed at the Magog site between the two assay dates. In fact, at the Bromptonville site, NRA of all clones was generally higher in the August assay compared to the July assay. This trend was not observed at the Magog site.

\subsection{Nitrate Reductase Activity in Relation to Soil Nitrate} Concentration. Significant relationships between $\mathrm{NO}_{3}{ }^{-}$concentration observed following a 24 day incubation period in riparian soils and nitrate reductase activity (NRA) were only observed for two of the studied clones: DxN-3570 $\left(R^{2}=\right.$ $0.39, P<0.1)$ and MxB-915311 $\left(R^{2}=0.63, P<0.05\right)$ (Figure 5). A positive relationship (power function) between $\mathrm{NO}_{3}{ }^{-}$and NRA was observed for clone DxN-3570, while a negative relationship (power function) between those two variables was observed for clone MxB-915311.

\section{Discussion}

In this study, leaf NRA differences of more than one order of magnitude were observed between the hybrid poplar clones, a clear indication of their different abilities to reduce $\mathrm{NO}_{3}{ }^{-}$in leaves. Clone $\mathrm{DxN}-3570$ had the greatest leaf NRA (1) during the enzyme kinetic assays at different substrate concentrations (Figure 2), (2) in leaves of different developmental stages (Figure 3), and (3) during both assays under field conditions in two contrasted sites in terms of soil $\mathrm{NO}_{3}$ availability (Figure 3). Large differences in leaf NRA have also been reported in other species of Populus [25, 32].

In addition, large differences in nitrification rate and soil $\mathrm{NO}_{3}{ }^{-}$availability across the two riparian sites (Tables 1 and 3 ) induced a clone-specific response in leaf NRA. This resulted in a significant Site $\mathrm{x}$ Clone interaction during the mid July and late August assays, with clone DxN-3570 having a significantly higher leaf NRA at the Bromptonville site, where $\mathrm{NO}_{3}{ }^{-}$availability is high, compared to the Magog site (Figure 4). Conversely, leaf NRA of the four other clones (TxD-3230, MxN-3729, MxB-915311, and DNxM-915508) was generally much lower and similar between clones and between sites (Figure 2). This suggests that clone DxN3570 has a particular ability to activate the $\mathrm{NO}_{3}{ }^{-}$reduction process in its leaves in response to a higher $\mathrm{NO}_{3}{ }^{-}$availability in the soil.

Based on previous findings, higher leaf NRA from all clones could be expected at Bromptonville given the higher soil $\mathrm{NO}_{3}{ }^{-}$availability at this site. As reported by Black et al. [33] and Rosenstiel et al. [34], higher leaf NRA values were found in poplars grown on soils with higher external $\mathrm{NO}_{3}{ }^{-}$ concentrations. Our field-based study showed that this relationship was only true for clone $\mathrm{DxN}-3570$. This resulted in a positive relationship between soil $\mathrm{NO}_{3}{ }^{-}$availability 


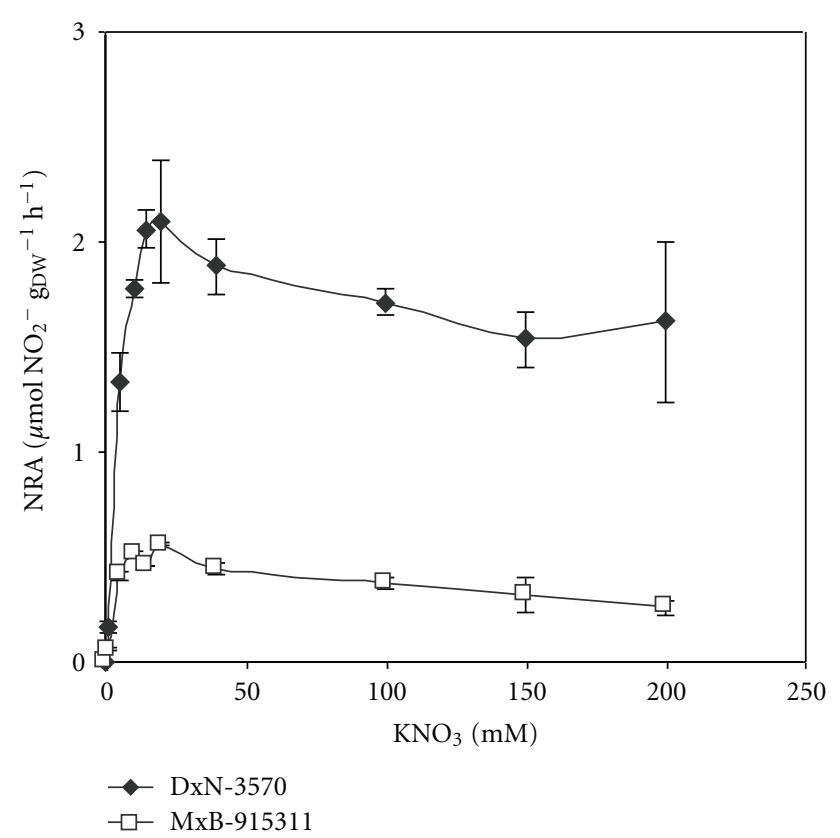

FIGURE 2: Effect of substrate concentration on nitrate reductase activity (NRA) of clone DxN-3570 and clone MxB-915311. All data points are means of duplicate samples and vertical bars represent $\mathrm{SD}$ of the means.

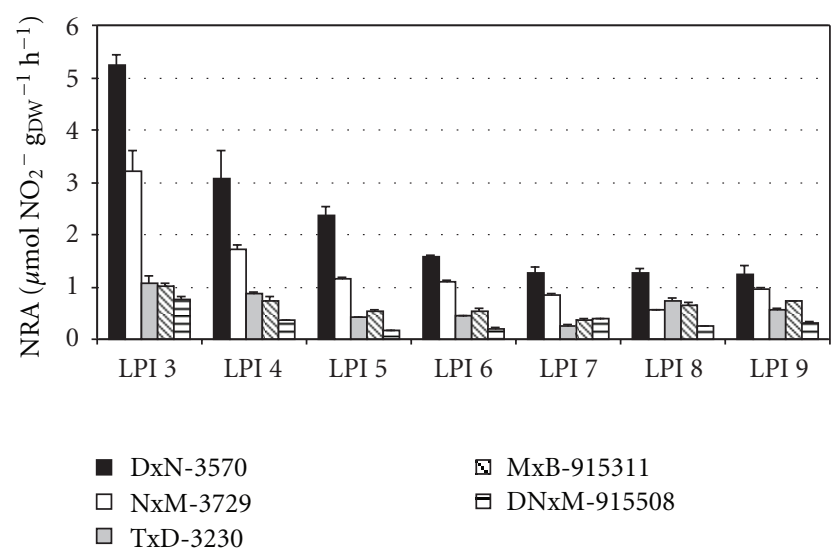

FIGURE 3: Effect of leaf age (developmental stage) on nitrate reductase activity (NRA) of five hybrid poplar clones. Leaf plastochron index (LPI) is used as an indicator of leaf age. All data points are means of duplicate sample analyses and vertical bars represent SD of the means.

measured across the two sites and leaf NRA for this clone $\left(R^{2}=0.39, P<0.1\right)$ (Figure 5), a positive relationship that was not observed for the other clones.

It could also be argued that the $\mathrm{NO}_{3}{ }^{-}$reduction process in hybrid poplars grown at the Bromptonville site was diluted in a much larger biomass compared to the Magog site (Table 1). An inverse relationship between dry biomass and NRA was also reported in Robinia pseudoacacia [50]. However, this dilution effect was not observed for clone DxN-3570 in this study.
As proposed earlier by Dykstra [32], we suggest that important leaf NRA differences among unrelated hybrid poplars reflect the genetic assemblage, or parentage, of the five clones studied. The parental species of clone DxN-3570 (P. deltoides and P. nigra) are typical colonisers of floodplain habitats of temperate and arid climates, where best growth occurs on sandy loam soils [11]. In those habitats, the predominant $\mathrm{N}$-form in soils is generally $\mathrm{NO}_{3}{ }^{-}$because of the warm climate and good soil drainage (water table below $30 \mathrm{~cm}$ of soil surface) $[17,36]$.

Studies on Eastern cottonwood ( $P$. deltoides) also suggests that a $60-80 \% \mathrm{NO}_{3}{ }^{-}$(balanced with $\mathrm{NH}_{4}{ }^{+}$) solution optimizes whole-plant growth [14]. Moreover, Woolfolk and Friend [20] found that greatest total root length, specific root length, and $\mathrm{N}$ concentration of roots in enriched patches occurred at the $80: 20 \mathrm{NO}_{3}{ }^{-}: \mathrm{NH}_{4}{ }^{+}$ratio. These observations are consistent with the particular ability of the clone DxN-3570 to increase its NRA in riparian environments with high $\mathrm{NO}_{3}{ }^{-}$availability, as observed at Bromptonville (Tables 1 and 3, Figure 4). High leaf NRA in response to a high $\mathrm{NO}_{3}{ }^{-}: \mathrm{NH}_{4}{ }^{+}$ratio in soils has also been reported in red ash (Fraxinus pennsylvanica), a common early succession species of rich alluvial bottomlands [23].

The relatively low leaf NRA in hybrid poplar clones that have a Tacamahaca section genetic contribution may be related to the soil $\mathrm{N}$-form preferences of these clones. It is well known that boreal species, such as balsam poplar, show a marked preference for the uptake of $\mathrm{NH}_{4}{ }^{+}$over $\mathrm{NO}_{3}{ }^{-}$, as observed for other species growing in cold climates [13]. In addition, south of the boreal forest, balsam poplar typically colonises wet soils found at the edges of streams and lakes, in swamps and depressions [11]. In those habitats, where the water table is near the soil surface, ammonification is generally the dominant $\mathrm{N}$-mineralization process and $\mathrm{NH}_{4}{ }^{+}$generally accumulates in the top soil [17]. During fertilisation trials, DesRochers et al. [19] also pointed out that $P$. balsamifera and two other clones related to the Tacamahaca section were better adapted for $\mathrm{NH}_{4}{ }^{+}$uptake rather than that of $\mathrm{NO}_{3}{ }^{-}$.

Furthermore, balsam poplar and other poplars related to the Tacamahaca section are known to have high concentrations of tannins and other phenolic compounds in their leaves and fine roots $[51,52]$. Once entered into the soil system through litter fall and fine root decomposition, these secondary compounds have a major effect on the $\mathrm{N}$ cycle, including a decrease in N-fixation from competitive species such as alder (Alnus), an increase in $\mathrm{N}$ immobilisation and a decrease in nitrification [51, 52]. Consequently, the physiological traits of low leaf NRA in clones related to the Tacamahaca section (Figures 2, 3 and 4) is consistent with the ability of poplars from this section to modify the environment, in order to reduce $\mathrm{NO}_{3}$ availability, at their own advantage.

Our observations also suggest a negative relationship between leaf NRA and soil $\mathrm{NO}_{3}{ }^{-}$concentration $\left(R^{2}=\right.$ $0.63, P<0.05)$ for the Tacamahaca intrasectional hybrid $(\mathrm{MxB})$ (Figure 5$)$. This is potentially the sign of a negative feedback of prolonged exposure to high soil $\mathrm{NO}_{3}{ }^{-}$concentrations on leaf NRA. 


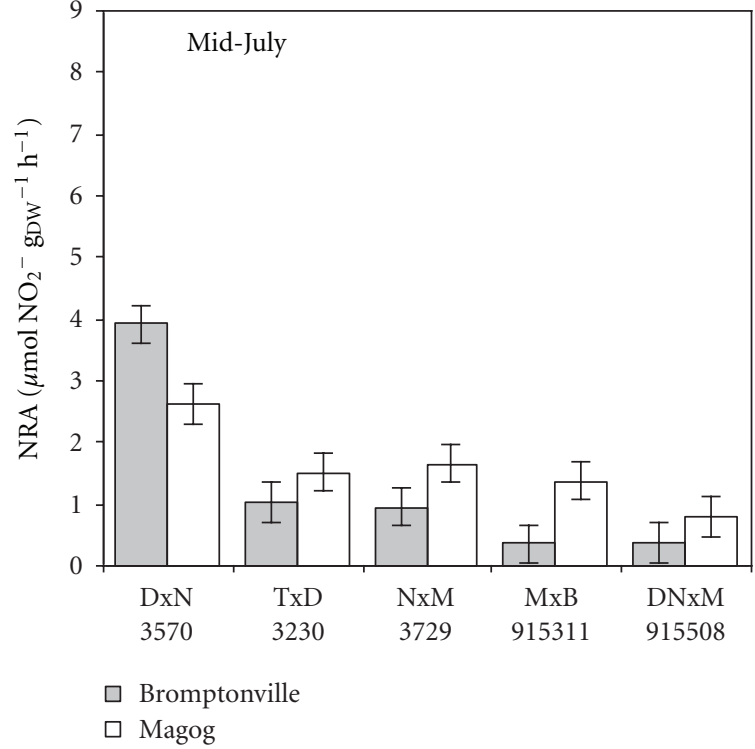

(a)

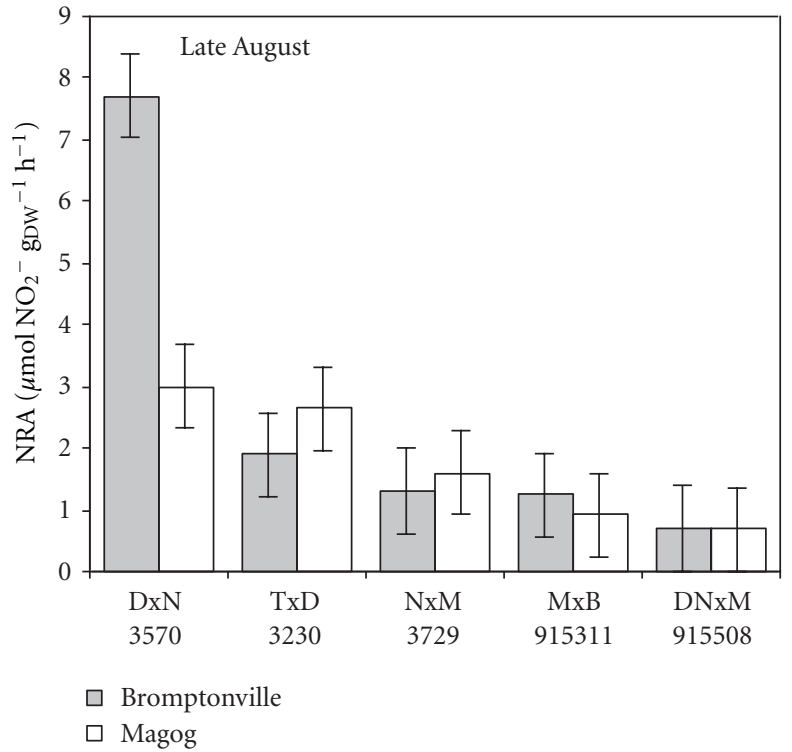

(b)

FIGURE 4: Nitrate reductase activity (NRA) of the five hybrid poplar clones at the two riparian buffer sites. On the left (a), the NRA assay was done in mid-July (July 10 and 11, 2007) and Site $\mathrm{x}$ Clone interaction is significant at $P<0.05$. On the right (b), NRA assay was done in late August (August 28 and 29, 2007) and Site $\mathrm{x}$ Clone interaction is significant at $P<0.01$. Vertical bars represent SE of the means.

Nitrate reductase activity observed in this study was neither a good indicator of mean aboveground biomass accumulation nor of $\mathrm{N}$ accumulation because the clone with the highest NRA (DxN-3570) (Figures 2, 3, and 4) had the lowest biomass growth and $\mathrm{N}$ accumulation among the five clones studied $[1,41]$. In a greenhouse study with 12 week-old trees originating from cuttings, Dykstra [32] also reported that leaf NRA was not an index of $\mathrm{N}$ assimilation in hybrid poplars. But, this author observed that the poplar clone with the highest NRA had a significantly higher dry stem weight, dry leaf weight, and height growth. This was not the case in our field study during the fifth growing season. However, further research is needed to determine if NRA might be a good indicator of growth among hybrid poplar clones of the same parentage.

Other components of productivity that have important genetic variation among poplar species may have affected clone growth, whether they are structural or physiological [8]. This includes leaf morphology and leaf growth [53], leaf photosynthetic capacity [54], nutrient requirements [55], nutrient-use efficiency [56], water-use efficiency [57], lightuse efficiency [58], phenotypic plasticity in response to differential $\mathrm{N}$ availability [59], early-rooting ability and rooting patterns [60-62], size, distribution and orientation of leaves and branches [63-65], wood density [66], and so forth. A favourable combination of many of these morphological, physiological and phenological characteristics explains the superior growth of selected hybrid poplar clones [8].

Finally, a clearer portrait of NRA in the set of clones studied here may have been obtained if NRA in roots had been tested in parallel to leaf NRA. Given that very low NRA was found in the leaves of some clones (DNxM-915508 and MxB-915311), it could also be suggested that $\mathrm{NO}_{3}{ }^{-}$ assimilation is relatively important in the roots of some clones and hybrid types, as shown in trembling aspen and balsam poplar $[21,29]$. Given the high genetic variability in physiological traits of poplar species, generalities such as that nitrate assimilation is almost entirely restricted to leaves in poplars [33], should be made with caution.

Although different poplar species and hybrids may have soil $\mathrm{N}$-form preferences, trees from the genus Populus are considered generalist pioneer species, capable of thriving on low and high $\mathrm{NO}_{3}{ }^{-}$or $\mathrm{NH}_{4}{ }^{+}$sites [67]. Still, future research is needed to clearly understand soil $\mathrm{N}$-form preferences among unrelated hybrid poplar clones and its potential relationship with NRA. If this relationship is proven, NRA could provide interesting information on the suitability and adaptability of different hybrid poplar clones to different fertilisation treatments [36] or to various plantation environments (clearcut forests, cultivated fields, abandoned farmland, riparian buffers, contaminated sites, etc.). In that context, it may be important to understand which $\mathrm{N}$-form is preferred by different parental species from both Tacamahaca and Aigeiros sections, and how hybridization between and within those two sections influences $\mathrm{N}$-form preferences and mechanisms of $\mathrm{N}$ assimilation.

\section{Conclusion}

This study has shown large variation in leaf NRA among hybrid poplars, with NRA differences of more than one order of magnitude for the hybrids studied (DxN, TxD, $\mathrm{NxM}, \mathrm{DNxM}$, and $\mathrm{MxB}$ ). Clone DxN-3570, an Aigeiros 


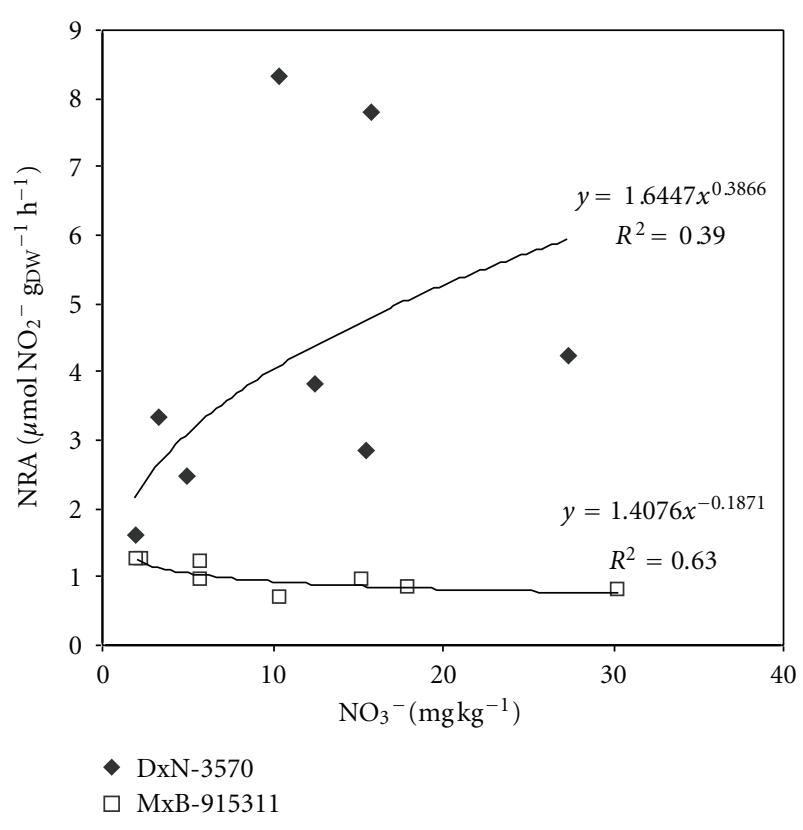

FIGURE 5: Relationship between $\mathrm{NO}_{3}{ }^{-}$concentration observed following a 24 day incubation period in riparian soils and nitrate reductase activity (NRA) for clone DxN-3570 $(P<0.1)$ and MxB915311 $(P<0.05)$. NRA values in this figure were obtained by averaging NRA values of the mid-July and late August assays.

intrasectional hybrid, always had the highest leaf NRA during the assays under field conditions. Across the two riparian sites, this clone was also the only one to increase its leaf NRA with increasing $\mathrm{NO}_{3}{ }^{-}$soil availability, which resulted in a significant Site $\mathrm{x}$ Clone interaction, but also a positive relationship between soil $\mathrm{NO}_{3}{ }^{-}$concentration and NRA. All four other clones studied had one or both parental species from the Tacamahaca section. They also had relatively low leaf NRA and they did not increase their leaf NRA when grown on the $\mathrm{NO}_{3}{ }^{-}$rich site, which sharply contrasts with the physiological response observed for the DxN hybrid in terms of leaf NRA. These results suggest that $\mathrm{NO}_{3}{ }^{-}$ assimilation in leaves varies widely among hybrid poplars of different parentages suggesting potential soil $\mathrm{N}$-forms preferences under genetic control.

\section{Acknowledgments}

The authors gratefully acknowledge funding received from the Ministère des Ressources naturelles et de la Faune du Québec (MRNF), the Ministère de l'Agriculture, des Pêcheries et de l'Alimentation du Québec (MAPAQ), Agriculture et Agroalimentaire Canada (AAC), and the Conférence régionale des élus de l'Estrie. The authors are very grateful to the landowners, M. Beauregard and J. Lamontagne, who allowed the planting of the buffers on their farms. The authors would also like to thank Nathalie Boulanger, Pierre-Olivier Émond, Guillaume Fleury, and Marie-Claude Giroux who assisted with field work. Thanks are also due to Claire Vasseur of the Biodôme de Montréal for facilitating soil analyses. Finally, a scholarship from the Fiducie de recherche sur la forêt des Cantons-de-l'Est to J. Fortier is gratefully acknowledged.

\section{References}

[1] J. Fortier, D. Gagnon, B. Truax, and F. Lambert, "Biomass and volume yield after 6 years in multiclonal hybrid poplar riparian buffer strips," Biomass and Bioenergy, vol. 34, no. 7, pp. 1028-1040, 2010.

[2] I. Laureysens, J. Bogaert, R. Blust, and R. Ceulemans, "Biomass production of 17 poplar clones in a short-rotation coppice culture on a waste disposal site and its relation to soil characteristics," Forest Ecology and Management, vol. 187, no. 2-3, pp. 295-309, 2004.

[3] L. A. Licht and J. G. Isebrands, "Linking phytoremediated pollutant removal to biomass economic opportunities," Biomass and Bioenergy, vol. 28, no. 2, pp. 203-218, 2005.

[4] J. A. Stanturf, C. van Oosten, M. D. Coleman, and C. J. Portwood, "Ecology and silviculture of poplar plantations," in Poplar Culture in North America, D. I. Dickmann, J. G. Isebrands, J. E. Eckenwalder, and J. Richardson, Eds., pp. 153-206, NRC Research Press, National Research Council of Canada, Ottawa, ON, Canada, 2001.

[5] M. Oelbermann, R. Paul Voroney, and A. M. Gordon, "Carbon sequestration in tropical and temperate agroforestry systems: a review with examples from Costa Rica and southern Canada," Agriculture, Ecosystems and Environment, vol. 104, no. 3, pp. 359-377, 2004.

[6] B. Truax, D. Gagnon, J. Fortier, and F. Lambert, "Yield in 8 year-old hybrid poplar plantations on abandoned farmland along climatic and soil fertility gradients," Forest Ecology and Management, vol. 267, pp. 228-239, 2012.

[7] J. Fortier, D. Gagnon, B. Truax, and F. Lambert, "Understory plant diversity and biomass in hybrid poplar riparian buffer strips in pastures," New Forests, vol. 42, no. 2, pp. 241-265, 2011.

[8] H. D. Bradshaw, R. Ceulemans, J. Davis, and R. Stettler, "Emerging model systems in plant biology: poplar (Populus) as a model forest tree," Journal of Plant Growth Regulation, vol. 19, no. 3, pp. 306-313, 2000.

[9] J. E. Eckenwalder, "Descriptions of clonal characteristics," in Poplar Culture in North America. Part B, D. I. Dickmann, J. G. Isenbrands, J. E. Eckenwalder, and J. Richardson, Eds., chapter 13, pp. 331-382, NRC Research Press, National Research Council of Canada, Ottawa, ON, Canada, 2001.

[10] D. E. Riemenschneider, B. J. Stanton, G. Vallée, and P. P. Périnet, "Poplar breeding strategies. Part A," in Poplar Culture in North America, D. I. Dickmann, J. G. Isebrands, J. E. Eckenwalder, and J. Richardson, Eds., chapter 2, pp. 43-76, NRC Research Press, National Research Council of Canada, Ottawa, ON, Canada, 2001.

[11] D. I. Dickmann and Y. A. Kuzovkina, "Poplars and willows of the world, with emphasis on silviculturally important species," Working Paper IPC/9-2, FAO Forest Management Division, Rome, Italy, 2008.

[12] J. E. K. Cooke and S. B. Rood, "Trees of the people: the growing science of poplars in Canada and worldwide," Canadian Journal of Botany, vol. 85, no. 12, pp. 1103-1110, 2007.

[13] F. S. Chapin, K. Van Cleve, and P. R. Tryon, "Relationship of ion absorption to growth rate in taiga trees," Oecologia, vol. 69, no. 2, pp. 238-242, 1986. 
[14] W. T. M. Woolfolk, Influence of ammonium:nitrate ratio on growth and $N$ accumulation of Populus deltoides [M.S. thesis], Mississippi State University, Starkville, Miss, USA, 2000.

[15] M. C. Leirós, C. Trasar-Cepeda, S. Seoane, and F. Gil-Sotres, "Dependence of mineralization of soil organic matter on temperature and moisture," Soil Biology and Biochemistry, vol. 31, no. 3, pp. 327-335, 1999.

[16] K. G. Cassman and D. N. Munns, "Nitrogen mineralization as affected by soil moisture, temperature, and depth," Soil Science Society of America Journal, vol. 44, no. 6, pp. 1233-1237, 1980.

[17] M. Hefting, J. C. Clément, D. Dowrick et al., "Water table elevation controls on soil nitrogen cycling in riparian wetlands along a European climatic gradient," Biogeochemistry, vol. 67, no. 1, pp. 113-134, 2004.

[18] K. Kielland, J. McFarland, and K. Olson, "Amino acid uptake in deciduous and coniferous taiga ecosystems," Plant and Soil, vol. 288, no. 1-2, pp. 297-307, 2006.

[19] A. DesRochers, R. Van Den Driessche, and B. R. Thomas, "The interaction between nitrogen source, soil $\mathrm{pH}$, and drought in the growth and physiology of three poplar clones," Canadian Journal of Botany, vol. 85, no. 11, pp. 1046-1057, 2007.

[20] W. T. M. Woolfolk and A. L. Friend, "Growth response of cottonwood roots to varied $\mathrm{NH} 4: \mathrm{NO}_{3}$ ratios in enriched patches," Tree Physiology, vol. 23, no. 6, pp. 427-432, 2003.

[21] X. Min, M. Y. Siddiqi, R. D. Guy, A. D. M. Glass, and H. J. Kronzucker, "Induction of nitrate uptake and nitrate reductase activity in trembling aspen and lodgepole pine," Plant, Cell and Environment, vol. 21, no. 10, pp. 1039-1046, 1998.

[22] X. Min, M. Y. Siddiqi, R. D. Guy, A. D. M. Glass, and H. J. Kronzucker, "A comparative study of fluxes and compartmentation of nitrate and ammonium in early-successional tree species," Plant, Cell and Environment, vol. 22, no. 7, pp. 821830, 1999.

[23] B. Truax, F. Lambert, D. Gagnon, and N. Chevrier, "Nitrate reductase and glutamine synthetase activities in relation to growth and nitrogen assimilation in red oak and red ash seedlings: effects of $\mathrm{N}$-forms, $\mathrm{N}$ concentration and light intensity," Trees, vol. 9, no. 1, pp. 12-18, 1994.

[24] W. H. Campbell, "Nitrate reductase and its role in nitrate assimilation in plants," Physiologia Plantarum, vol. 74, no. 1, pp. 214-219, 1988.

[25] A. Al Gharbi and C. R. Hipkin, "Studies on nitrate reductase in british angiosperms. I. A comparison of nitrate reductase activity in ruderal, woodland-edge and woody species," New Phytologist, vol. 97, no. 4, pp. 629-639, 1984.

[26] F. Lambert, B. Truax, D. Gagnon, and N. Chevrier, "Growth and $\mathrm{N}$ nutrition, monitored by enzyme assays, in a hardwood plantation: effects of mulching materials and glyphosate application," Forest Ecology and Management, vol. 70, no. 13, pp. 231-244, 1994.

[27] M. A. Nicodemus, K. F. Salifu, and D. F. Jacobs, "Nitrate reductase activity and nitrogen compounds in xylem exudate of Juglans nigra seedlings: relation to nitrogen source and supply," Trees, vol. 22, no. 5, pp. 685-695, 2008.

[28] N. Smirnoff, P. Todd, and G. R. Stewart, "The occurrence of nitrate reduction in the leaves of woody plants," Annals of Botany, vol. 54, no. 3, pp. 363-374, 1984.

[29] L. Koyama and K. Kielland, "Plant physiological responses to hydrologically mediated changes in nitrogen supply on a boreal forest floodplain: a mechanism explaining the discrepancy in nitrogen demand and supply," Plant and Soil, vol. 342, no. 1-2, pp. 129-139, 2011.
[30] B. Truax, D. Gagnon, and N. Chevrier, "Nitrate reductase activity in relation to growth and soil $\mathrm{N}$ forms in red oak and red ash planted in three different environments: forest, clearcut and field," Forest Ecology and Management, vol. 64, no. 1, pp. 71-82, 1994.

[31] B. Truax, D. Gagnon, F. Lambert, and N. Chevrier, "Nitrate assimilation of raspberry and pin cherry in a recent clearcut," Canadian Journal of Botany, vol. 72, no. 9, pp. 1343-1348, 1994.

[32] G. F. Dykstra, "Nitrate reductase activity and protein concentration of two Populas clones," Plant Physiology, vol. 53, pp. 632-634, 1974.

[33] B. L. Black, L. H. Fuchigami, and G. D. Coleman, "Partitioning of nitrate assimilation among leaves, stems and roots of poplar," Tree Physiology, vol. 22, no. 10, pp. 717-724, 2002.

[34] T. N. Rosenstiel, A. L. Ebbets, W. C. Khatri, R. Fall, and R. K. Monson, "Induction of poplar leaf nitrate reductase: a test of extrachloroplastic control of isoprene emission rate," Plant Biology, vol. 6, no. 1, pp. 12-21, 2004.

[35] R. T. W. Siegwolf, R. Matyssek, M. Saurer et al., "Stable isotope analysis reveals differential effects of soil nitrogen and nitrogen dioxide on the water use efficiency in hybrid poplar leaves," New Phytologist, vol. 149, no. 2, pp. 233-246, 2001.

[36] H. Rennenberg, H. Wildhagen, and B. Ehlting, "Nitrogen nutrition of poplar trees," Plant Biology, vol. 12, no. 2, pp. 275291, 2010.

[37] K. M. Klingensmith and K. V. Cleve, "Patterns of nitrogen mineralization and nitrification in floodplain successional soils along the Tanana River, interior Alaska," Canadian Journal of Forest Research, vol. 23, no. 5, pp. 964-969, 1993.

[38] A. Robitaille and J. P. Saucier, Paysages Régionaux Du Québec Méridional, Les publications du Québec, Ste-Foy, QC, Canada, 1998.

[39] J.-P. Saucier, J.-F. Bergeron, P. Grondin, and P. Robitaille, "Les régions écologiques du Québec méridional (3e version): un des éléments du système hiérarchique de classification écologique du territoire mis au point par le ministère des Ressources naturelles du Québec," L'Aubelle, vol. 124, pp. 112, 1998 .

[40] D. B. Cann and P. Lajoie, Etudes des Sols des Comtés de Stanstead, Richmond, Sherbrooke et Compton dans la Province de Québec, Ministère de l'Agriculture, Ottawa, Canada, 1943.

[41] J. Fortier, D. Gagnon, B. Truax, and F. Lambert, "Nutrient accumulation and carbon sequestration in 6-year-old hybrid poplars in multiclonal agricultural riparian buffer strips," Agriculture, Ecosystems and Environment, vol. 137, no. 3-4, pp. 276-287, 2010.

[42] P. Périnet, H. Gagnon, and S. Morin, Liste des Clones Recommandés de Peuplier Hybride par Sous-Région écologique au Québec (Révision Février 2001), Direction de la Recherche Forestière, MRN, Québec, Canada, 2001.

[43] R. G. D. Steel and J. H. Torrie, Principles and Procedures of Statistics, McGraw-Hill, New York, NY, USA, 1980.

[44] P. Qian, J. J. Schoenau, and W. Z. Huang, "Use of ion exchange membranes in routine soil testing," Communications in Soil Science \& Plant Analysis, vol. 23, no. 15-16, pp. 1791-1804, 1992.

[45] R. J. Raison, M. J. Connell, and P. K. Khanna, "Methodology for studying fluxes of soil mineral-N in situ," Soil Biology and Biochemistry, vol. 19, no. 5, pp. 521-530, 1987.

[46] D. R. Keeney and D. W. Nelson, "Nitrogen: inorganic forms," in Methods of Soil Analysis: Part 2, A. L. Page, R. H. Miller, 
and D. R. Keeney, Eds., pp. 643-698, American Society of Agronomy, Madison, Wis, USA, 1982.

[47] E. G. Jaworski, "Nitrate reductase assay in intact plant tissues," Biochemical and Biophysical Research Communications, vol. 43, no. 6, pp. 1274-1279, 1971.

[48] P. R. Larson and J. G. Isebrands, "The plastochron index as applied to developmental studies of cottonwood," Canadian Journal of Forest Research, vol. 1, no. 1, pp. 1-11, 1971.

[49] R. G. Peterson, Design and Analysis of Experiments, MarcelDekker, New York, NY, USA, 1985.

[50] K. H. Johnson, B. C. Bongarten, and L. R. Boring, "Effects of nitrate on in viva nitrate reductase activity of seedlings from three open-pollinated families of Robinia pseudoacacia," Tree Physiology, vol. 8, pp. 381-389, 1991.

[51] J. P. Schimel, R. G. Cates, and R. Ruess, "The role of balsam poplar secondary chemicals in controlling soil nutrient dynamics through succession in the Alaskan taiga," Biogeochemistry, vol. 42, no. 1-2, pp. 221-234, 1998.

[52] J. A. Schweitzer, M. D. Madritch, J. K. Bailey et al., "From genes to ecosystems: the genetic basis of condensed tannins and their role in nutrient regulation in a Populus model system," Ecosystems, vol. 11, no. 6, pp. 1005-1020, 2008.

[53] C. R. Ridge, T. M. Hinckley, R. F. Stettler, and E. Van Volkenburgh, "Leaf growth characteristics of fast-growing poplar hybrids Populus trichocarpa $x$ P. deltoides," Tree Physiology, vol. 1, pp. 209-216, 1986.

[54] T. S. Barigah, B. Saugier, M. Mousseau, J. Guittet, and R. Ceulemans, "Photosynthesis, leaf area and productivity of 5 poplar clones during their establishment year," Annales des Sciences Forestieres, vol. 51, no. 6, pp. 613-625, 1994.

[55] P. Heilman and R. J. Norby, "Nutrient cycling and fertility management in temperate short rotation forest systems," Biomass and Bioenergy, vol. 14, no. 4, pp. 361-370, 1998.

[56] L. S. Lodhiyal and N. Lodhiyal, "Nutrient cycling and nutrient use efficiency in short rotation, high density central Himalayan Tarai poplar plantations," Annals of Botany, vol. 79, no. 5, pp. 517-527, 1997.

[57] T. J. Blake, T. J. Tschaplinski, and A. Eastham, "Stomatal control of water use efficiency in poplar clones and hybrids," Canadian Journal of Botany, vol. 62, no. 7, pp. 1344-1351, 1984.

[58] M. G. R. Cannell, L. J. Sheppard, and R. Milne, "Light use efficiency and woody biomass production of poplar and willow," Forestry, vol. 61, no. 2, pp. 125-136, 1988.

[59] J. E. K. Cooke, T. A. Martin, and J. M. Davis, "Shortterm physiological and developmental responses to nitrogen availability in hybrid poplar," New Phytologist, vol. 167, no. 1, pp. 41-52, 2005.

[60] D. S. Green, E. L. Kruger, and G. R. Stanosz, "Effects of polyethylene mulch in a short-rotation, poplar plantation vary with weed-control strategies, site quality and clone," Forest Ecology and Management, vol. 173, no. 1-3, pp. 251-260, 2003.

[61] J. A. Zalesny, R. S. Zalesny, D. R. Coyle, R. B. Hall, and E. O. Bauer, "Clonal variation in morphology of Populus root systems following irrigation with landfill leachate or water during 2 years of establishment," Bioenergy Research, vol. 2, no. 3, pp. 134-143, 2009.

[62] R. M. A. Block, K. C. J. Van Rees, and J. D. Knight, "A review of fine root dynamics in Populus plantations," Agroforestry Systems, vol. 67, no. 1, pp. 73-84, 2006.

[63] R. Ceulemans, R. F. Stettler, T. M. Hinckley, J. G. Isebrands, and P. E. Heilman, "Crown architecture of Populus clones as determined by branch orientation and branch characteristics," Tree Physiology, vol. 7, pp. 157-167, 1990.

[64] J. G. Isebrands and D. A. Michael, "Effects of leaf morphology and orientation on solar radiation interception and photosynthesis in Populus," in Crown and Canopy Structure in Relation To Productivity, T. Fujimori and D. Whitehead, Eds., pp. 359381, Forestry and Forest Products Research Institute, Ibaraki, Japan, 1986.

[65] J. M. Dunlap and R. F. Stettler, "Genetic variation and productivity of Populus trichocarpa and its hybrids. X. Trait correlations in young black cottonwood from four river valleys in Washington," Trees, vol. 13, no. 1, pp. 28-39, 1998.

[66] A. Pliura, S. Y. Zhang, J. MacKay, and J. Bousquet, "Genotypic variation in wood density and growth traits of poplar hybrids at four clonal trials," Forest Ecology and Management, vol. 238, no. 1-3, pp. 92-106, 2007.

[67] X. Min, M. Y. Siddiqi, R. D. Guy, A. D. M. Glass, and H. J. Kronzucker, "A comparative kinetic analysis of nitrate and ammonium influx in two early-successional tree species of temperate and boreal forest ecosystems," Plant, Cell and Environment, vol. 23, no. 3, pp. 321-328, 2000. 

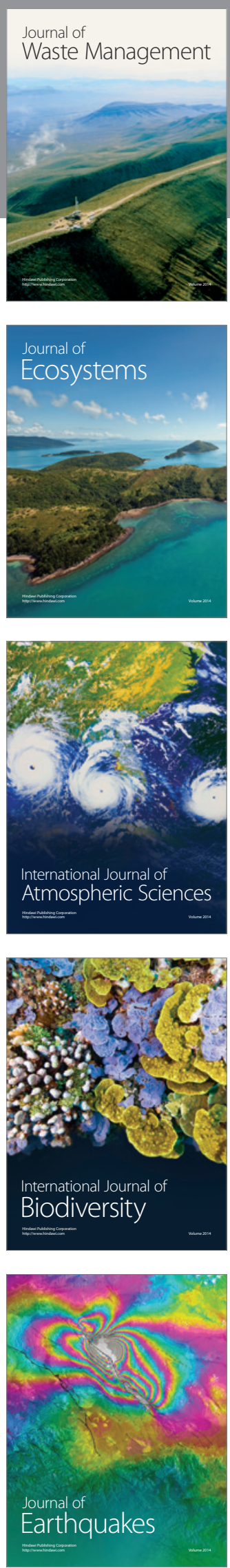
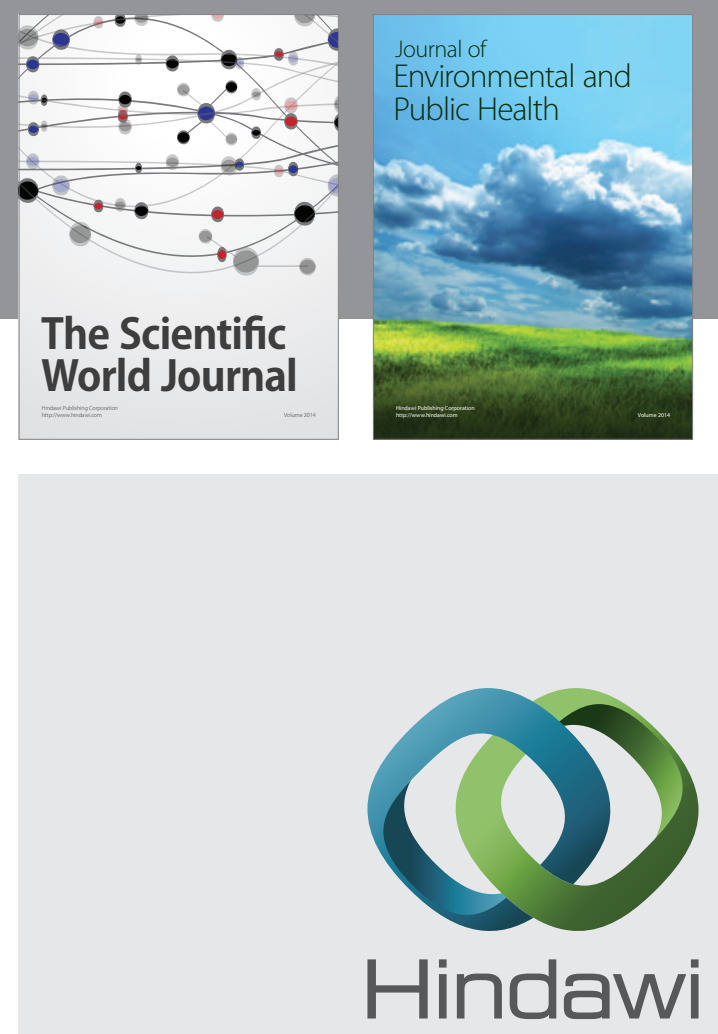

Submit your manuscripts at

http://www.hindawi.com
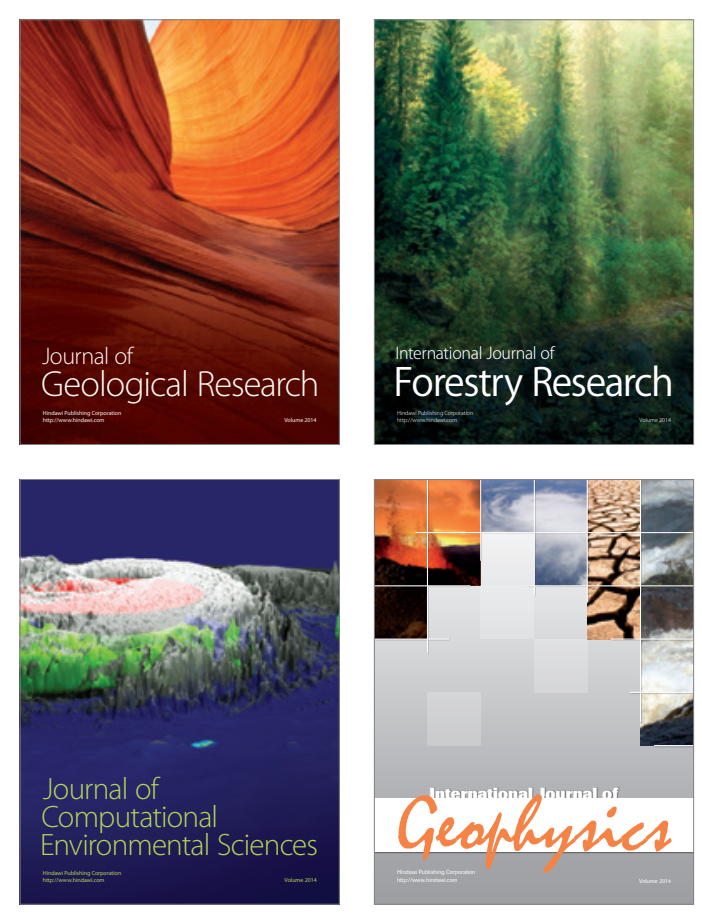
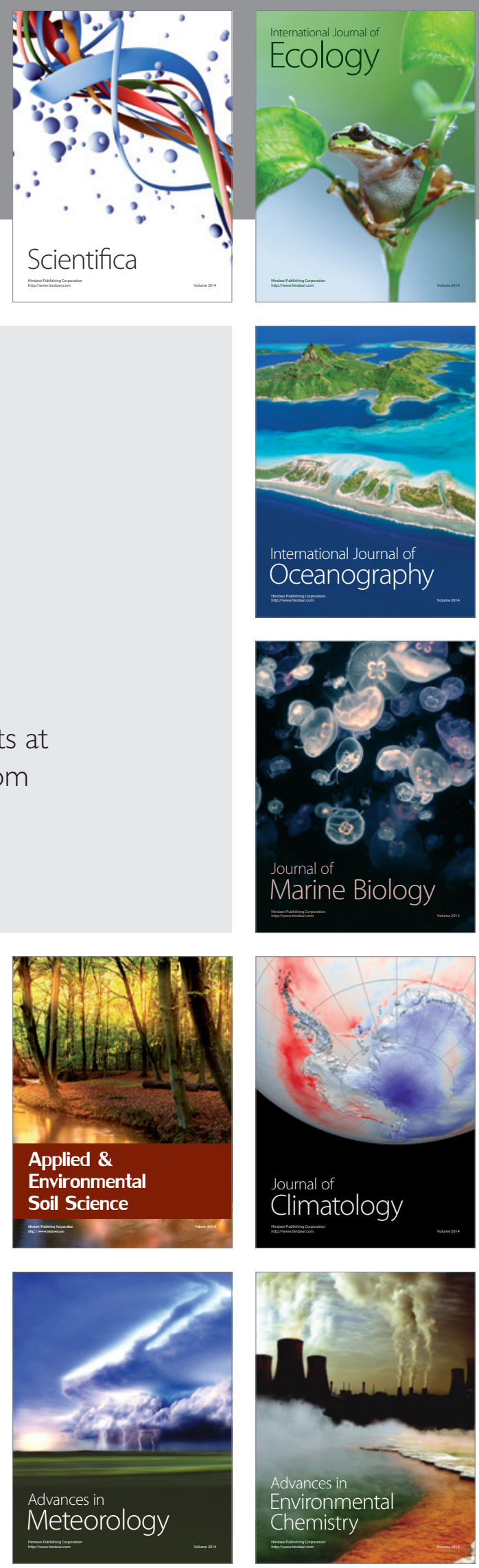